Cornell Law Library

Scholarship@Cornell Law: A Digital Repository

Cornell Law Faculty Publications

Faculty Scholarship

$1-1-2002$

\title{
Plaintiphobia in the Appellate Courts: Civil Rights Really Do Differ from Negotiable Instruments
}

Kevin M. Clermont

Cornell Law School,kmc12@cornell.edu

Theodore Eisenberg

Cornell Law School, ted-eisenberg@lawschool.cornell.edu

Follow this and additional works at: http://scholarship.law.cornell.edu/facpub

Part of the Civil Procedure Commons, Civil Rights and Discrimination Commons, $\underline{\text { Courts }}$ Commons, and the Litigation Commons

\section{Recommended Citation}

Clermont, Kevin M. and Eisenberg, Theodore, "Plaintiphobia in the Appellate Courts: Civil Rights Really Do Differ from Negotiable Instruments" (2002). Cornell Law Faculty Publications. Paper 220.

http://scholarship.law.cornell.edu/facpub/220

This Article is brought to you for free and open access by the Faculty Scholarship at Scholarship@Cornell Law: A Digital Repository. It has been accepted for inclusion in Cornell Law Faculty Publications by an authorized administrator of Scholarship@Cornell Law: A Digital Repository. For more information, please contact jmp8@cornell.edu. 


\title{
PLAINTIPHOBIA IN THE APPELLATE COURTS: CIVIL RIGHTS REALLY DO DIFFER FROM NEGOTIABLE INSTRUMENTS
}

\author{
Kevin M. Clermont* \\ Theodore Eisenberg**
}

\begin{abstract}
Professors Clermont and Eisenberg conducted a systematic analysis of appellate court behavior and report that defendants have a substantial advantage over plaintiffs on appeal. Their analysis attempted to control for different variables that may affect the decision to appeal or the appellate outcome, including case complexity, case type, amount in controversy, and whether there had been a judge or a jury trial. Once they accounted for these variables and explored and discarded various alternate explanations, they came to the conclusion that a defendants' advantage exists probably because of appellate judges' misperceptions that trial level adjudicators are pro-plaintiff.
\end{abstract}

Authors' Summary: Using a database that combines all federal civil trials and appeals decided since 1988, we find that defendants succeed more than plaintiffs on appeal from civil trials. Defendants that appeal their losses after trial obtain reversals at a $33 \%$ rate, while losing plaintiffs succeed in only $12 \%$ of their appeals from trials. Both descriptive analyses of the results and more formal regression models dispel explanations based solely on selection of cases; instead, they support an explanation based on appellate judges' attitudes toward trial level adjudicators. The large difference between appellate and trial court decisions probably stems from the appellate judges' misperceptions about the trial level treatment of plaintiffs. Consequently, the appellate court is more favorably disposed to the defendant than either the trial judge or the jury.

* Flanagan Professor of Law, Cornell University. We would like to thank participants at the 2001 University of Illinois College of Law empiricism conference and especially thank the organizers, Tom Ulen and Richard McAdams.

** Henry Allen Mark Professor of Law, Cornell University. 


\section{INTRODUCTION}

"Let me tell you about the very rich. They are different from you and me." "Yes, they have more money."

Data show that classic riposte to be true. Do they show that the rich do better on appeal as well?

Until we created new data, by building a bridge between the trial and appellate databases of the Administrative Office of the United States Courts, it was impossible to systematically follow individual cases through the federal court system. One could study trial outcomes or appellate outcomes, but the absence of a statistical bridge between the two threw an opaque veil over the whole litigation process. With the bridge finally built and the new database created, we can explore for the first time all sorts of serious questions.

We initially decided to pursue our earlier judge/jury research. ${ }^{3}$ We studied thirteen sizable tort and contract case categories that most clearly lead to a choice between judge and jury trial. We also eliminated cases in which the United States was the defendant, because there is usually no jury right in these cases. This study, tracing these civil jury trials through appeal, revealed that jury trials as a group are not special on appeal. ${ }^{4}$ Instead, we found a striking plaintiff/defendant difference. ${ }^{5}$ Defendants succeeded surprisingly more than plaintiffs on appeal from civil trials, and especially from jury trials. Defendants that appealed their losses after trial obtained reversals at a $28 \%$ rate, while losing plaintiffs succeeded in only $15 \%$ of their appeals, with the spread increasing to $31 \%$ and $13 \%$ for appeals from jury trials. $^{6}$

Normally, when one sees such a difference in outcomes, one's first reaction should be to investigate whether differing input has produced the outcome pattern. One should ask, were defendants' appeals stronger on the merits than plaintiffs' appeals? Because the set of cases selected for litigation can be a biased sample of the underlying disputes, it can be difficult to conclude anything by simply looking at outcome data. That is, selection effect often renders outcome data ambiguous. ${ }^{7}$ Upon further investi-

1. F. SCOTt Fitzgerald, The Rich Boy, in The Diamond as Big as THE RITZ and Other STORIES 139 (1962).

2. ERnest Hemingway, The Snows of Kilimanjaro, in The Snows of Kilimanjaro and OTHER STORIES 23 (1995).

3. Kevin M. Clermont \& Theodore Eisenberg, Trial by Jury or Judge: Transcending Empiricism, 77 CORNELL L. REv. 1124 (1992) [hereinafter Clermont \& Eisenberg, Transcending Empiricism].

4. Kevin M. Clermont \& Theodore Eisenberg, Appeal from Jury or Judge Trial: Defendants' Advantage, 3 AM. L. \& ECON. REv. 125, 130 (2001) [hereinafter Clermont \& Eisenberg, Appeal].

5. See id.; see also Kevin M. Clermont \& Theodore Eisenberg, Anti-Plaintiff Bias in the Federal Appellate Courts, 84 JudiCATURE 128 (2000) [hereinafter Clermont \& Eisenberg, Anti-Plaintiff Bias] (study of appellate outcomes showing that defendants are more successful on appeals from civil cases).

6. Clermont \& Eisenberg, Appeal, supra note 4, at 131 tbl.1.

7. See Kevin M. Clermont \& Theodore Eisenberg, Do Case Outcomes Really Reveal Anything About the Legal System? Win Rates and Removal Jurisdiction, 83 CORNELL L. Rev. 581, 588-91 (1998) [hereinafter Clermont \& Eisenberg, Win Rates]. 
gation, however, case selection for appeal turned out to be more of a random sampling than a systematic screening. Thus, the appellate stage marked a fresh start in the case selection process, a clean break from the trial stage. Moreover, any selection of cases for appeal seemed to reflect little or no systematic filtering on the basis of case strength. This absence of selection effect allowed us to interpret the outcome data in a straightforward way. For example, if defendants prevail more often than plaintiffs on appeal, then that suggests that appellate courts favor defendants more than trial courts.

Appellate courts are indeed more favorable to defendants than are trial judges and juries. We concluded that the defendants' higher reversal rate stems from real but hitherto unappreciated attitudinal differences between appellate and trial courts. These differences are probably owing to the appellate judges' misperceptions regarding the trial level treatment of plaintiffs. The appellate judges seem to act on their perceptions of the trial courts' being pro-plaintiff. That tendency would be appropriate if the trial courts were in fact biased in favor of the plaintiff. As empirical evidence has accumulated refuting a trial court bias, however, the appellate judges' perceptions increasingly appear to be misperceptions. If misperceptions are in play, then this appellate leaning in favor of the defendant is a cause for concern.

In brief, both descriptive analyses of the results and more formal regression models dispelled explanations based solely on selection of cases and supported an explanation based on appellate judges' attitudes toward trial level adjudicators. Further investigation revealed that the defendants' advantage grew as the case better fit the format of little victim against big defendant, just as it grew when the case had been decided by a jury. We found these tendencies in personal injury cases, as well as in cases involving nongovernmental, noncorporate, nonforeign, and in-state plaintiffs. These tendencies supported our theory that the appellate courts were striving to undo trial level favoritism toward plaintiffs, which the appellate judges were imagining. In sum, our thesis was a simple one: misperceptions exist, and they have effects; more specifically, widespread misperceptions of the trial process exist, and these misperceptions affect the appellate outcomes for plaintiffs and defendants.

With the judge/jury distinction more or less off the table, we are now prepared to investigate more broadly this plaintiff/defendant difference. For this article, we include all the cases in all the case categories, rather than the subset of cases involving a clear choice between judge and jury trial. In the three main parts of this article, we shall (i) describe our methods, (ii) recount our observations, and (iii) forward some explanations of what we have seen. In the end, the appellate playing field still appears unlevel. 


\section{Methods}

Data gathered by the Administrative Office of the United States Courts, assembled by the Federal Judicial Center, and disseminated by the Inter-university Consortium for Political and Social Research convey details of all cases terminated in the federal courts since fiscal year $1970 .{ }^{8}$ When a civil case terminates in a federal district court or court of appeals, the court clerk transmits a form containing information about the case to the Administrative Office. The form includes: data regarding the names of the parties, the subject matter category, the jurisdictional basis, the case's origin in the district as original, removed, or transferred, the amount demanded, the dates of filing and termination in the district court or the court of appeals, the procedural stage of the case at termination, the procedural method of disposition, and, if the court entered judgment or reached decision, who prevailed. Thus, the computerized database, compiled from these forms, contains all of the millions of federal civil cases over many years from the entire country. ${ }^{9}$

We needed to limit this database to those cases that would best reveal how appeals affect the outcomes of civil trials. Therefore, we limited the set to cases terminated in fiscal years 1988-1997, because these years allowed us to trace the cases from the trial to the appellate level. ${ }^{10}$ Unlike our earlier study, this time we included all the cases in all the different case categories. In some of the analyses, however, we separately analyzed the twenty-three case categories that contained at least fifty cases showing decisive outcome on appeal, while lumping all the other small categories of cases into a twenty-fourth catch-all group of Others.

Next, we had to clean up this reduced data set. We eliminated duplicate case records, and adjusted for cross, consolidated, and reopened appeals - with insubstantial effect. ${ }^{11}$ We made these refinements to limit the set to include only cases for which we could reliably match district and appellate data.

8. See 11 Admin. OfFice OF THE U.S. CourTs, Statistics MANuAl ch. I, at $7-43$ (June 1989) (court of appeals); 11 ADMIN. OFFICE OF THE U.S. COURTS, GUIDE TO JUDICIARY POLICIES AND PROCEDURES transmittal 64, at II-18 to -28 (Mar. 1, 1985) (district court). For a complete description of the Administrative Office database, see INTER-UnIV. CONSORTIUM FOR POLTICAL \& SOC. RESEARCH, FEDERAL COURT CASES: INTEGRATEd DATA BASE, 1970-1997, ICPSR 8429 (1998). For an evaluation of this database, see Clermont \& Eisenberg, Win Rates, supra note 7, at 585-87. See generally Theodore Eisenberg \& Kevin M. Clermont, Courts in Cyberspace, 46 J. LEGAL EdUC. 94 (1996) (discussion of the Judicial Statistical Inquiry Form).

9. Theodore Eisenberg \& Kevin M. Clermont, Judicial Statistical Inquiry Form, at http://teddy. law.cornell.edu:8090/questata.htm (last modified Nov. 15, 1998).

10. In fiscal year 1988, the Administrative Office started including the district court docket number in its courts of appeals' data set. Currently, fiscal year 1997 is the last year available. In order to include those appeals that had not yet terminated by September 30,1997, and thereby accurately to calculate the appeal rate, we added the set of appellate cases pending in fiscal year 1997. We were able to do this because court clerks transmit a form upon each case filing, as well as upon each case termination.

11. That is to say, running similar analyses without making these refinements yielded essentially the same results, but we do not report them here. 
Finally, we were ready to match the district data to the appellate data. To do this, we matched the district court's docket number and filing date in the district data set with the corresponding information in the appellate data set. Our ultimate aim was to compute the appeal rate and, among the decided appeals, the reversal rate.

First, the appeal rate is, in general, the percentage of terminated district court cases that reach the appellate court docket. By segregating the cases of the district court that gave an express judgment for either the plaintiff or the defendant, one can calculate a plaintiffs' appeal rate and a defendants' appeal rate. Initially, if the judgment below was for the plaintiff, we inferred that the defendant was the appellant. However, an examination of the parties' names revealed that in more than a quarter of these cases, a dissatisfied plaintiff was the appellant. So, we simply discarded such cases where the plaintiff was the named appellant or the defendant was the named appellee. ${ }^{12}$ Thus, by looking at the remaining appeals, we are comparing only appeals brought by parties that had judgments entered against them. So, for our purposes, the appeal rate is the percentage of district court judgments formally for one side that the other side puts on the appellate court docket.

Second, the reversal rate is the percentage of these appeals that reach a decisive outcome and emerge as reversed rather than affirmed. We define the appellate outcome of "reversed" as comprising three codes: reversed, remanded, and affirmed in part and reversed in part. We narrowly define "affirmed" as comprising only the codes for affirmed and dismissed on the merits. After having established these parameters, one can readily calculate a plaintiffs' reversal rate and a defendants' reversal rate.

\section{OBSERVATIONS}

Table 1 combines all case categories and shows some instructive aggregate patterns. The defendants' appeal rate, in both judge and jury civil trials, is higher than the plaintiffs' appeal rate. The "Totals" column shows that defendants appeal about $31 \%$ of their trial losses, while plaintiffs appeal about $27 \%$. Although defendants are somewhat less selective about the cases they appeal, fewer of their appeals result in a decisive outcome. That is, defendants seem to drop more appeals than do plaintiffs, so that a smaller percentage of defendant trial losses conclude in a decisive appellate outcome. In fact, defendants pursue about $9 \%$ of their trial losses to a decisive appellate outcome, while plaintiffs pursue about $15 \%$. But across case

12. If we were somehow to treat rather than discard that special category of appeals-appeals by plaintiffs from judgment for plaintiff - the effect would be to raise the defendants' appeal rate, because the denominator (plaintiffs' wins at trial) would decrease. Moreover, if we were to recognize that these cases and others might involve plaintiff trial losses despite the formal judgment for plaintiff, the effect would be to lower the plaintiffs' trial win rate. (Incidentally, the reversal rate for that special category of appeals is virtually identical to the defendants' reversal rate.) 
categories, there is no correlation between any of these rates and the parties' relative success rates on appeal.

In any event, defendants obtain appellate reversals of trial losses at a much higher rate than do plaintiffs. Defendants' trial losses are reversed in about $33 \%$ of their appeals, whereas plaintiffs' trial losses are reversed in about $12 \%$ of their appeals. Thus, the previously observed asymmetry in reversal rates survives inclusion of all case categories.

TABLE 1

APPEALS FROM FEDERAL CIVIL TRIALS BY JURY OR JUDGE, FY1988-1997

FURTHER DISTINGUISHED BY PLAINTIFF OR DEFENDANT WIN AT TRIAL

\begin{tabular}{lccc}
\hline & $\begin{array}{c}\text { Jury } \\
\text { Trials }\end{array}$ & $\begin{array}{c}\text { Judge } \\
\text { Trials }\end{array}$ & Totals \\
\hline $\begin{array}{l}\text { Overall number of trial judg- } \\
\text { ments }\end{array}$ & 31,806 & 28,799 & 60,605 \\
Appeal rate (\%) & $\mathbf{2 8 . 5 2}$ & $\mathbf{2 8 . 9 6}$ & $\mathbf{2 8 . 7 3}$ \\
Affirmances \& reversals & 3,579 & 3,799 & 7,378 \\
Reversal rate (\%) & $\mathbf{2 0 . 4 0}$ & $\mathbf{1 6 . 4 5}$ & $\mathbf{1 8 . 3 7}$ \\
Number of plaintiff trial wins & 14,136 & 11,901 & 26,037 \\
Defendants' appeal rate (\%) & $\mathbf{3 2 . 3 4}$ & $\mathbf{3 0 . 0 9}$ & $\mathbf{3 1 . 3 1}$ \\
Affirmances \& reversals & 1,244 & 1,034 & 2,278 \\
Defendants' reversal rate (\%) & $\mathbf{3 4 . 3 2}$ & $\mathbf{3 0 . 3 7}$ & $\mathbf{3 2 . 5 3}$ \\
Number of defendant trial wins & 17,670 & 16,898 & 34,568 \\
Plaintiffs' appeal rate (\%) & $\mathbf{2 5 . 4 7}$ & $\mathbf{2 8 . 1 6}$ & $\mathbf{2 6 . 7 8}$ \\
Affirmances \& reversals & 2,335 & 2,765 & 5,100 \\
Plaintiffs' reversal rate (\%) & $\mathbf{1 2 . 9 8}$ & $\mathbf{1 1 . 2 5}$ & $\mathbf{1 2 . 0 4}$ \\
\hline
\end{tabular}

Source: Administrative Office data.

Table 2 shows that this reversal-rate advantage of defendants does not depend on particular categories of cases. We define the defendant/plaintiff differential, given in the "D/P Differential" columns, to be the defendants' reversal rate minus the plaintiffs' reversal rate. Because this differential, reported in the penultimate column, has a positive sign for every category except "Negotiable Instruments," there is a pervasive pattern. Defendants fare better on appeal than do plaintiffs.

The defendant/plaintiff differential in the larger categories is significant. The biggest differentials occur in the civil rights categories. Indeed, the size of this differential in those cases merits separate discussion in Part IV.C. below. 
Negotiable Instruments, although exhibiting an insignificant negative differential, might be the exception that proves the rule. This case category is peculiar in several regards. ${ }^{13}$ The Negotiable Instruments category, with its image of a substantial plaintiff who is relying on documentary proof, is least likely to inspire fear in appellate courts of a pro-plaintiff bias at the trial court level.

Although Table 2 shows that the defendants' advantage on appeal exists in almost every case category, the differential between plaintiffs and defendants varies substantially across case categories. For convenience, we divide federal cases into six major groups: Contracts, Torts, Civil Rights, Labor Laws, Miscellaneous Statutory Actions, and Others. For four of these groups (Contracts, Labor Laws, Miscellaneous Statutory Actions, and Others), the defendant/plaintiff differential is relatively modest, ranging from about $5 \%$ in Others to almost $12 \%$ in Labor Laws. To put these differentials in perspective, they are not substantially different from the size of the reversal-rate differential between "haves" and "have nots" found in published state-court opinions. ${ }^{14}$ In the Torts and Civil Rights groups, however, the defendant/plaintiff differential swells to about $20 \%$ and $36 \%$, respectively. ${ }^{15}$ Table 2's last column, which reports the significance level of the differential, shows it to be most significant in these two groups as well.

In results not reported here, we have confirmed that the prodefendant pattern prevails in all federal circuits. Furthermore, regression analysis that accounts for mode of trial (judge or jury), case category, year, and circuit confirms the higher defendants' reversal rate. The prodefendant appellate pattern also survives the use of a proxy variable to account for case complexity. ${ }^{16}$ Regression results for specific case groupsContracts, Torts, and Civil Rights - are reported in Part IV.D.2. below.

\section{EXPLANATIONS}

\section{A. Prior Explanations}

Our prior works emphasized the difference in appellate court and trial court attitudes toward plaintiffs as an explanation for the defen-

13. It is also the category with the smallest percentage of its trials being by jury. Our earlier article showed that its defendant/plaintiff reversal rates for judge trials are $11 \% / 33 \%$, but Negotiable Instruments sees the more typical rates of $38 \% / 20 \%$ for jury trials. See Clermont \& Eisenberg, Appeal, supra note 4 , at 136 .

14. See Stanton Wheeler et al., Do the "Haves" Come Out Ahead? Winning and Losing in State Supreme Courts, 1870-1970, 21 LAW \& SOC'Y REV. 403, 438-39 (1987); infra text accompanying notes 5154.

15. Within the Contracts group, the category that may be the most tort-like (cases involving insurance) has the largest differential.

16. We included a variable equal to the difference between each case's time on the district court docket and the mean time for that case's category in its circuit. It serves as a proxy for complexity and is often significant. It suggests that more complex cases tend to be reversed. See infra Table 3. 


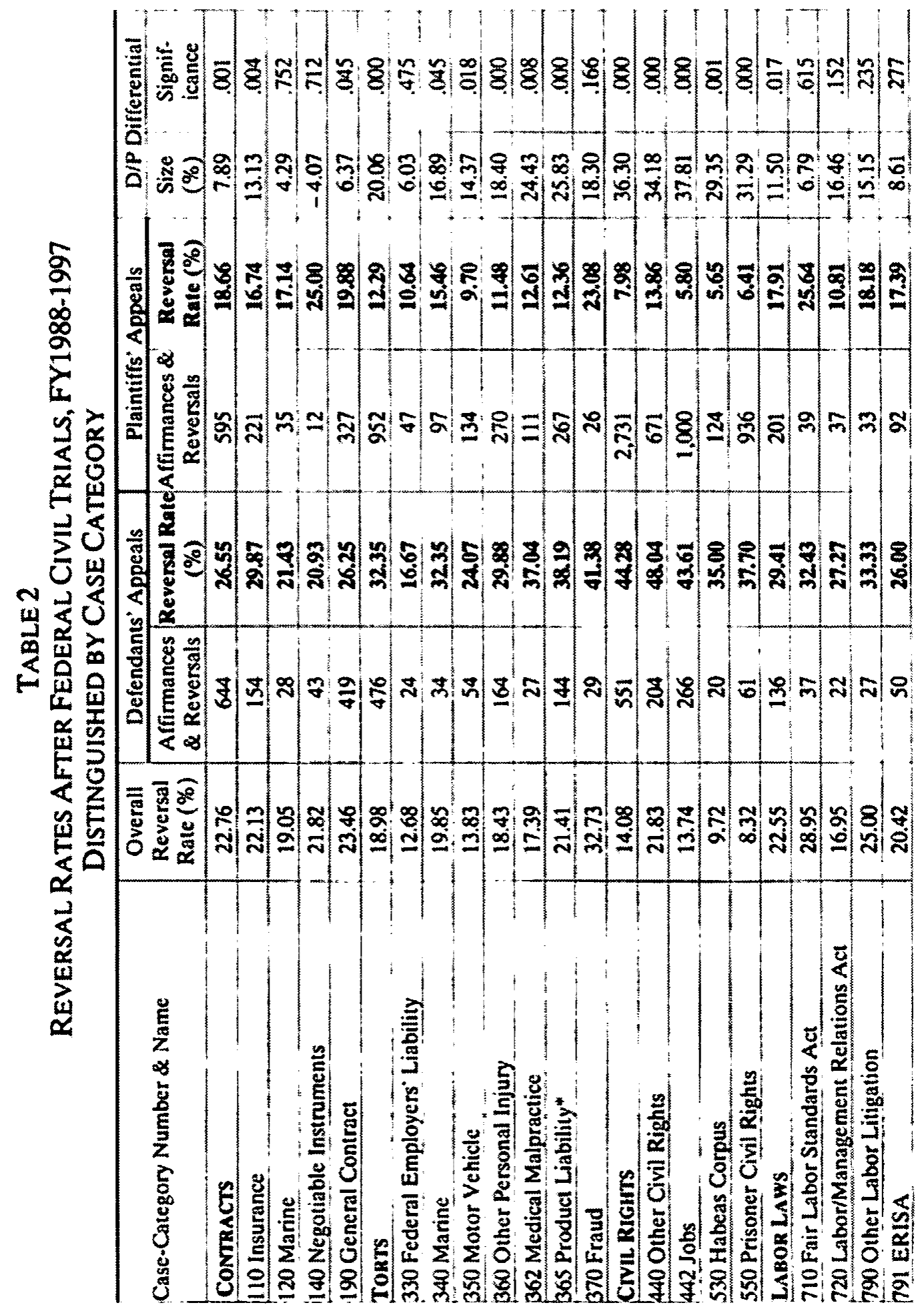




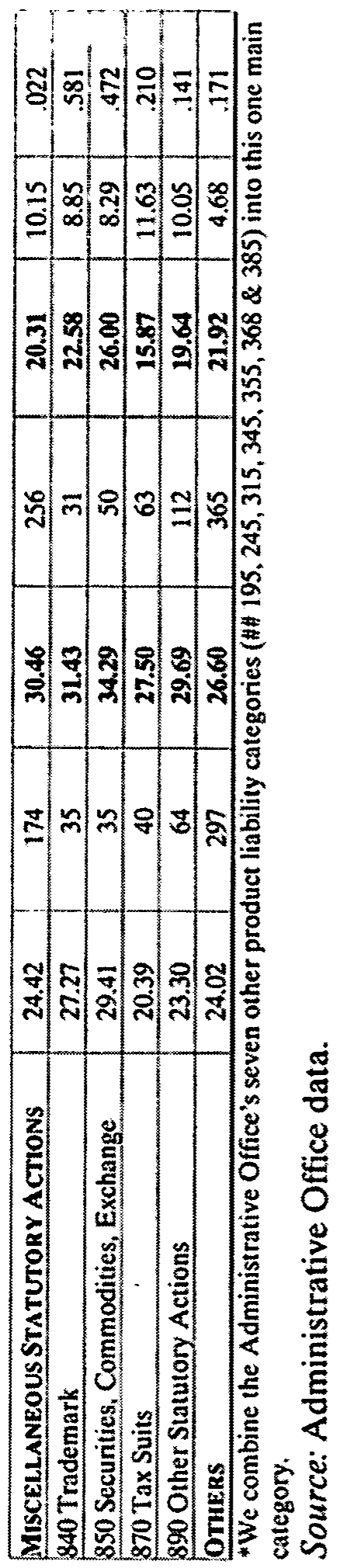


dant/plaintiff differential. ${ }^{17}$ As described above, appellate courts perceive trial courts to be pro-plaintiff and, consciously or unconsciously, seek to correct this perceived trial court bias. This conclusion supports the hypothesis of other researchers that appellate courts "are more removed from direct contact with "underdog' parties than lower court judges." 18

In arriving at this conclusion, we discussed and rejected other possible explanations, including political differences between appellate and trial judges, and also the parties' selection of cases for appeal, which turns on such things as the parties' differential stakes, their differing settlement incentives, and their relative rationality in deciding what to appeal. ${ }^{19} \mathrm{We}$ will not repeat that discussion, most of which applies here.

Instead, we first consider some additional explanations and conclude that they are unlikely to explain the data fully. Then, we consider how the evidence from the added case categories, especially civil rights cases, bears on our attitudinal explanation. Finally, we explore more formal models that jointly estimate the decision to appeal and the appellate outcome. These models confirm that Torts and Civil Rights are the two groups in which appellate court review of trial outcomes is most hostile to plaintiffs.

\section{B. Newer Explanations}

One might leap to attribute the observed defendant/plaintiff differential to a kind of conjunction effect. The thought behind such an explanation is that plaintiffs must succeed on all issues to win, while defendants need prevail on only one. There might indeed be an anti-plaintiff effect in the trial court, where plaintiffs sometimes have to prove a conjunction of elements. However, there should be no such effect on appeal. True, a losing defendant will pick one or more points to appeal (and selection and settlement should narrow these down to points on which the merits are a fairly close call), and if the defendant succeeds on any of these points, the appellate court will normally reverse. But similarly, after trial a losing plaintiff will pick one or more points that went against it, and if the plaintiff succeeds on any of these points, the appellate court will normally reverse. That is, if there was a single error against the plaintiff, reversal follows. Therefore, whether plaintiff or defendant, the appellee must succeed on all issues to preserve victory. In other words, there is no conjunction on appeal that works against plaintiffs as a class.

Another possible explanation is that defendants' counsel may have greater ability on appeal, such as in writing briefs, than plaintiffs' counsel. Plaintiff tort lawyers may not be the most skilled brief writers, even if they

17. See generally Clermont \& Eisenberg, Appeal, supra note 4; Clermont \& Eisenberg, AntiPlaintiff Bias, supra note 5.

18. Wheeler et al., supra note 14 , at 409 . For an account of recent charges that the Michigan appellate courts are anti-plaintiff, see Alan Fisk, Michigan Lawyers Clash over Bench Balance, NAT'L L.J., Oct. 29, 2001, at A6.

19. See Clermont \& Eisenberg, Appeal, supra note 4, at 143, 146-49. 
excel at trial. Additionally, many large defense firms have specialists in appeals. But this hypothesis has not found substantial empirical support in explaining overall appellate success rates. ${ }^{20}$ Furthermore, our prior study found that the reversal-rate advantage of defendants does not depend on the type of party. ${ }^{21}$ That study focused on diversity cases, where we could distinguish corporate from individual plaintiffs and defendants. We found a greater skill or resources explanation plausible but ultimately incomplete:

Corporate parties appeal more and obtain more reversals. But corporate defendants fare better than corporate plaintiffs as appellants, just as individual defendants fare better than individual plaintiffs as appellants. So, "haves" may do better than "have nots" on appeal because of more skill and greater resources, but there is a separate defendants' advantage worthy of study. ${ }^{22}$

Thus, a broad-based defendants' advantage exists on appeal, and an attitudinal explanation remains convincing after consideration of alternative explanations and contributing factors.

\section{The Especially Telling Case of Civil Rights}

To the extent the defendants' advantage rests on appellate court misperceptions of trial court pro-plaintiff leanings, one might expect the advantage to be strongest in cases systematically involving underdogs as plaintiffs, where appellate court suspicion of trial court sympathy might be at its maximum. Civil rights cases, with their near systematic feature of underdog plaintiffs, ${ }^{23}$ should, therefore, provide a useful test of our explanation.

The defendant/plaintiff differential is large in all the civil rights categories, but it is largest in the most numerous civil rights category, "Jobs," where minorities and females are the predominant types of plaintiffs. In these cases, plaintiffs obtain appellate reversals of trial wins by defendants in less than $6 \%$ of their appeals. In contrast, defendants obtain appellate reversals in nearly $44 \%$ of their appeals. This differential is, as Table 2's last column shows, highly statistically significant. Another computation is also telling. For the 266 cases appealed by defendants with a decisive appellate outcome, the $44 \%$ reversal rate is not statistically significantly different from a $50 \%$ reversal rate. ${ }^{24}$ One cannot reject the hypothesis that de-

20. See Wheeler et al., supra note 14 , at 432-37 (empirically rebutting this hypothesis, and concluding that the "aggregate advantage enjoyed by stronger parties in private law cases was not due simply to disparities in type of lawyer").

21. See Clermont \& Eisenberg, Appeal, supra note 4, at 136-38.

22. Id. (also distinguishing governmental parties).

23. See, e.g., Jon O. Newman, Suing the Lawbreakers: Proposals to Strengthen the Section 1983 Damage Remedy for Law Enforcers' Misconduct, 87 YALE L.J. 447, 454 (1978) (federal judge noting, "Except in those rare instances when the party injured is the white, middle-class victim of police mistake, the section 1983 plaintiff is likely to be black or Puerto Rican, poor, disheveled, a felon, and often a drug addict.").

24. This is based on a Fisher's exact test comparing the observed number of reversals, 116 of the 266 defendants' appeals, with a 50\% reversal rate, which would result in reversals in 133 of 266 appeals. The p-value is .164 . A similar computation for plaintiffs' appeals shows that their $5.80 \%$ reversal rate is 
fendants win half their appeals. Therefore, plaintiffs who prevail at trial face an appellate process that gives them as much chance of winning after appeal as of winning a coin flip.

Closer consideration of job discrimination cases strengthens an attitudinal explanation of the defendant/plaintiff differential. Job discrimination plaintiffs are one of the least successful classes of plaintiffs at the trial court level. ${ }^{25}$ In this category of cases, the plaintiffs win $30 \%$ of their tried cases. So if trial courts are unusually biased toward job discrimination plaintiffs, they must be starting with a class of cases that are truly abysmal for plaintiffs. More likely, trial courts process job discrimination cases with a neutral or even jaundiced eye toward plaintiffs. ${ }^{26}$

Then the defendants appeal $42.36 \%$ of their losses, although they take only $11.23 \%$ of their losses to decisive appellate outcome. The comparable numbers for plaintiffs are $31.97 \%$ and $18.24 \%$. It is here that the stark defendant/plaintiff differential kicks in. Table 2 shows that the $43.61 \%$ reversal rate for defendants' appeals in job discrimination cases is the second highest of all case categories. Only plaintiffs in the "Other Civil Rights" category are less successful in preserving their trial court victories, as they suffer a reversal rate of $48.04 \%$. This latter case category's performance reinforces the likelihood of anti-plaintiff appellate bias as an explanation. This category includes many discrimination, police misconduct, and First Amendment cases that may ultimately depend on the motives of official decision makers ${ }^{27}$ and that may create similar anti-plaintiff bias. Put in another perspective, prisoners have less difficulty maintaining their trial victories than do nonprisoner civil rights plaintiffs. ${ }^{28}$

The fact that plaintiffs in job discrimination cases are especially vulnerable on appeal is even more startling in light of the nature of these cases and the applicable standard of review. The vast bulk of job discrimination cases turn on intent, not on disparate impact, as Donohue and Siegelman have shown. ${ }^{29}$ The question of the defendant's intent is likely to be the key issue in a nonfrivolous job discrimination case that reaches trial. Once the plaintiff has convinced the fact finder of the defendant's wrongful intent, that finding should be largely immune from appellate reversal, just as defendants' trial victories are largely immune from reversal. Thus, reversal of

significantly different from a $50 \%$ reversal rate. The p-value is then close to zero. See STANTON A. GLANTZ, PRIMER OF BIOSTATISTICS 140-45 (4th ed. 1997).

25. See Clermont \& Eisenberg, Transcending Empiricism, supra note 3, at 1175.

26. Cf. Valerie P. Hans \& Nicole Vadino, Whipped by Whiplash? The Challenges of Jury Communication in Lawsuits Involving Connective Tissue Injury, 67 TENN. L. REV. 569, 572-73 (2000) (discussing evidence of anti-plaintiff sentiment among the public).

27. See Theodore Eisenberg \& Sheri Lynn Johnson, The Effects of Intent: Do We Know How Legal Standards Work?, 76 CORNELL L. REV. 1151, $1164-65$ (1991); Stewart J. Schwab \& Theodore Eisenberg, Explaining Constitutional Tort Litigation: The Influence of the Attorney Fees Statute and the Government as Defendant, 73 CORNELL L. REV. 719, 735 (1988).

28. See supra Table 2 (showing $35.00 \%$ and $37.70 \%$ reversal rates in defendants' appeals of "Habeas Corpus" and "Prisoner Civil Rights" cases, respectively).

29. See John J. Donohue III \& Peter Siegelman, The Changing Nature of Employment Discrimination Litigation, 43 STAN. L. REV. 983, 989, 998 \& n.57 (1991). 
plaintiffs' trial victories in job discrimination cases should be unusually uncommon. Yet we find the opposite.

\section{Modeling Selection and Decision of Appeals}

The unobservability of cases that are not appealed could be skewing the results observed in the cases that are appealed. If, for example, defendants appeal a very strong class of trial losses compared to plaintiffs, the selection of cases for appeal, rather than appellate court behavior, could explain the results in Table 2 . Because properly modeling appellate outcomes requires accounting for this selection decision, we use bivariate probit models that account for both (i) the decision to appeal to a decisive outcome and (ii) the outcome of those trials that are appealed.

Prior results from a smaller set of case categories indicated that appellate courts' pro-defendant stance survived this modeling process. ${ }^{30}$ Those results, which divided the smaller data set into the two major classes of personal injury and nonpersonal injury, nevertheless suggested important differences across classes of cases. ${ }^{31}$ The pro-defendant stance was much stronger in personal injury cases than in nonpersonal injury cases, and different factors explained the decision to appeal in the two classes of cases. These results suggest the desirability of modeling similar case categories together while separating highly disparate case categories.

\section{The Models}

We employ a modified version of our prior model of the decision to appeal to a decisive outcome. We first describe the factors previously used: the stakes of the case, the observed prior behavior of the appellate court in the case category being considered for appeal, the case category, the mode of trial, and the year of termination. We then describe a new variable as a proxy for case complexity. ${ }^{32}$

Economic theory suggests that the likelihood of appeal increases as the stakes of a case increase. We account for a case's stakes as follows: If the plaintiff won at trial and a nonzero award is reported, that award is deemed to be the case's stakes. If a nonzero award is not reported or if the plaintiff lost at trial, the stakes cannot be observed from the trial outcome. So, if the case's data contain a nonzero amount demanded, that demand is treated as the stakes. All amounts awarded and demanded are adjusted for

30. See Clermont \& Eisenberg, Appeal, supra note 4, at 149-53.

31. See id.

32. We exclude from our new model, and also from our model of appellate outcome, two groups of variables previously used. We previously included variables to account for the different propensities of individuals, corporations, and the government to litigate and to appeal. Data on corporate and individual status are available only for diversity cases, and our sample is no longer limited to such cases. We also previously included variables that tracked the origin of a district court case-whether it originated as an original matter in the trial court or via transfer or removal. Both groups of variables proved insignificant in the earlier models. See id. at 157, 159 tbl.A1. 
inflation to 1997 dollars, and all positive amounts are transformed to logs. If neither a nonzero award nor a nonzero demand exists for a case, the case is represented by a dummy variable, "missing stakes," equal to one in such cases and equal to zero in all cases for which an award or demand exists. Stakes are thus coded as missing in $41.02 \%$ of the 60,605 cases with trial judgments. ${ }^{33}$

We expect that prospects on appeal also influence the decision to appeal. For each circuit, case category, and trial outcome, we compute an overall reversal rate. For example, the reversal rates in the Sixth Circuit for product liability trials won by defendants and plaintiffs, respectively, are $8 \%$ and $38 \%$. Holding other factors constant, we expect parties to be more reluctant to appeal trial losses in circuits with lower reversal rates for their situation. If there are too few cases in a circuit to compute a meaningful reversal rate, the parties face increased uncertainty about the appellate outcome. Increased uncertainty should correlate with increased appeal rates. So, if there are fewer than ten observations within a circuit, we represent the increased uncertainty by a dummy variable, "missing reversal rate," equal to one in such cases and equal to zero in all cases for which we can compute a meaningful reversal rate. ${ }^{34}$

Case categories affect the routing of cases to either a judge or a jury trial and display sharply different trial outcomes. ${ }^{35}$ We therefore control for case category in two ways. First, we separately model the decision to appeal and appellate outcome for each of the six major case groups reported in Table 2: Contracts, Torts, Civil Rights, Labor Laws, Miscellaneous Statutory Actions, and Others. This avoids sharply different features of case groups from influencing one another. For example, the dominant mode of compensating attorneys varies across Contracts (hourly rate), Torts (contingent fee), and Civil Rights (statutory fee award) cases. Models that lump these groups of cases together might allow results from one group to influence the models at the expense of another group. Second, to further control for case category within the six models, we use dummy variables for each case category in each model. For example, we include dummy variables for the four categories of civil rights cases included in the Civil Rights model.

The parties' perceptions about how appellate courts react to jury trials versus judge trials, and toward plaintiff wins versus defendant wins, may affect the decision to appeal. We therefore include dummy variables representing how the case was tried and who prevailed. Also, the decision to ap-

33. Stakes are missing much less frequently in Contracts and Torts cases, $24.86 \%$ and $23.87 \%$, respectively, than in Civil Rights cases, in which stakes are missing in $56.37 \%$ of the cases. This difference presumably reflects the greater role of equitable relief in Civil Rights cases. Running the same models while omitting cases with missing stakes produced no material effect on the principal results.

34. We also ran models that replaced the missing affirmance rate with the national affirmance rate. They did not lead to results materially different from those reported here.

35. See Clermont \& Eisenberg, Transcending Empiricism, supra note 3, at 1137-38, 1167-70. 
peal may vary with the times. So, we include the year of termination as a control for any linear time trend in the data. ${ }^{36}$

To these variables, we add a new variable as a proxy for a tried case's complexity. It is the difference between each tried case's time on the district court docket and the mean time for that case's category in its circuit. The theory underlying this variable is that more complex cases are more likely to be appealed. In these cases, there is likely more room for trial court error and for parties' reasonable disagreement about rulings. ${ }^{37}$

Having modeled the decision to appeal, we next explore the outcome of those cases that are appealed. In modeling the appellate outcome of affirmance or reversal, the explanatory variables of primary interest are those characterizing trial outcome. Our prior results and Table 2 suggest that plaintiffs should be less likely to obtain reversals than defendants. Other factors-such as case category, mode of trial, and year-are obvious candidates for inclusion in the appellate outcome model in light of their importance in affecting trial outcomes. To capture intercircuit differences in inclination to reverse, we include dummy variables for each circuit. To account for the possible nonindependence of cases decided in the same district, we treat cases as clustered at the district level, resulting in adjusted standard errors.

As in the case of the decision to appeal, case complexity might be expected to correlate with the outcome of the appeal. More complex cases should yield more trial court rulings with greater uncertainty than less complex cases. Litigants should, on average, have more grounds for appeal, and the likelihood of error on an important issue should increase. So, we again add to our prior model a variable representing the difference between each tried case's time on the district court docket and the mean time for the case's category in its circuit.

\section{Empirical Results for Tried Cases}

We ran each model separately for the six major case groups. Table 3 reports the results for the key variables in the appellate outcome model for the three groups of prime interest: Contracts, Torts, and Civil Rights. The full models for all six groups appear in the Appendix.

Table 3's model in the first numerical column includes only Contracts cases, its second model includes only Torts cases, and its third model includes only Civil Rights cases. The variables are the same in all three models, except that the case-category dummy variables change to reflect the

36. We also ran models that included dummy variables for each year. They did not lead to results materially different from those reported here.

37. On the other hand, a long, complex case might make appellate courts more reluctant to overturn trial court rulings. We nevertheless find that this variable behaves in the manner suggested in the text. 
limitations to Contracts, Torts, and Civil Rights. The case categories included in each of the groups appear in Table 2.

Table 3's Torts and Civil Rights models show that Table 2's extreme defendant/plaintiff differential survives this more complete statistical analysis. The coefficients on the dummy variables "Plaintiff won judge trial" and "Plaintiff won jury trial" are substantially larger than the coefficients on the similar variables representing defendant wins at trial. And the differences are highly statistically significant. Therefore, in both of these areas of law, defendants are much more likely than plaintiffs to obtain reversal after a trial.

The results for the Contracts model are less extreme and show the defendants' advantage only on appeal from jury trials. ${ }^{38}$ In the Contracts model, the difference between defendants and plaintiffs for judge trials disappears and even changes sign. But the difference between defendants and plaintiffs for jury trials persists. A test of the significance of the difference between the "Defendant won jury trial" and "Plaintiff won jury trial" coefficients in this model is significant at the $p=.070$ level. In short, although the usual defendant/plaintiff differential in reversal rates is present in Torts and Civil Rights cases tried before both juries and judges, it is present in Contracts cases only tried before juries, and then at a marginally statistically significant level.

The Appendix reports results for the three groups not reported in Table 3. It shows, in Labor Laws, that the bivariate probit model yields modest differences between defendants' and plaintiffs' reversal rates. The difference is in the same direction as in Table 3's groups, and a test of the significance of the difference between the "Defendant won jury trial" and "Plaintiff won jury trial" coefficients is significant at $p=.099$. For the Miscellaneous Statutory Actions group, there are significant differences in reversal rates depending on whether plaintiff or defendant won at trial, judge or jury, with defendants more likely to achieve reversal. For the residual group of Others, there are significant differences in reversal rates in appeals from jury trials, with defendants again more likely to achieve reversal of trial defeats.

Thus, all six groups show significant or near significant anti-plaintiff effects on appeal. Plaintiffs do worse on appeal than defendants, even accounting for the selection of cases for appeal. The differential is greatest in the Torts and Civil Rights groups, which best fit the pattern of little victim against big defendant.

With respect to the effect of selection on the outcome models, the three models in Table 3 show rho $(\rho)$, which is a measure of the correlation

38. Our prior analysis distinguished between personal injury and nonpersonal injury cases rather than between contracts and torts cases, and limited the sample in ways not applicable here. That analysis showed no significant difference in defendant/plaintiff reversal rates in nonpersonal injury cases tried before judges but a significant difference in defendant/plaintiff reversal rates in nonpersonal injury cases tried before juries. See Clermont \& Eisenberg, Appeal, supra note 4, at 153. 
in the error terms in the selection and outcome equations, to be significant or of borderline significance. Thus, in these models, one should be hesitant to reject the hypothesis that the error terms are uncorrelated and that a simple logit or probit model would suffice. This measure, therefore, suggests the propriety of jointly modeling the decision to appeal and the outcome of the appeal. ${ }^{39}$

TABLE 3

BIVARIATE PROBIT MODELS OF APPELLATE OUTCOME

\begin{tabular}{|c|c|c|c|}
\hline \multicolumn{4}{|c|}{ dependent variable in outcome equation $=$ reversal of trial result } \\
\hline & Contracts & Torts & Civil Rights \\
\hline \multicolumn{4}{|c|}{ Trial outcome variables (defendant won judge trial $=$ reference category) } \\
\hline \multirow[t]{2}{*}{ Plaintiff won judge trial } & -.053 & $.942^{* * *}$ & $.824^{* *}$ \\
\hline & $(.123)$ & $(.131)$ & $(.293)$ \\
\hline \multirow[t]{2}{*}{ Defendant won jury trial } & -.102 & .120 & .051 \\
\hline & $(.100)$ & $(.082)$ & $(.052)$ \\
\hline \multirow[t]{2}{*}{ Plaintiff won jury trial } & .136 & $.723 * * *$ & $.701 * *$ \\
\hline & $(.147)$ & $(.119)$ & $(.256)$ \\
\hline \multirow[t]{2}{*}{ Complexity (log of difference from mean days) } & $.021^{* *}$ & .007 & $.015^{* * *}$ \\
\hline & $(.007)$ & $(.010)$ & $(.004)$ \\
\hline \multicolumn{4}{|c|}{$\begin{array}{l}\text { Other variables, and the Selection Equation, are reported in Table } 4 \text { and the Appendix } \\
\text { (panel A) }\end{array}$} \\
\hline \multirow[t]{2}{*}{$P$} & $.751 t$ & $-.695 * *$ & $.804 t$ \\
\hline & $(.232)$ & $(.149)$ & $(.222)$ \\
\hline Number of outcome observations & 1,239 & 1,428 & 3,282 \\
\hline
\end{tabular}

Source: Administrative Office data.

39. The Appendix shows $\rho$ to be insignificant in the groups of Labor Laws and Others, and significant at $\mathrm{p}=.069$ for Miscellaneous Statutory Actions. 
TABLE 4

Bivariate Probit Models of THE DECISION TO APPEAL AFter TRIAL

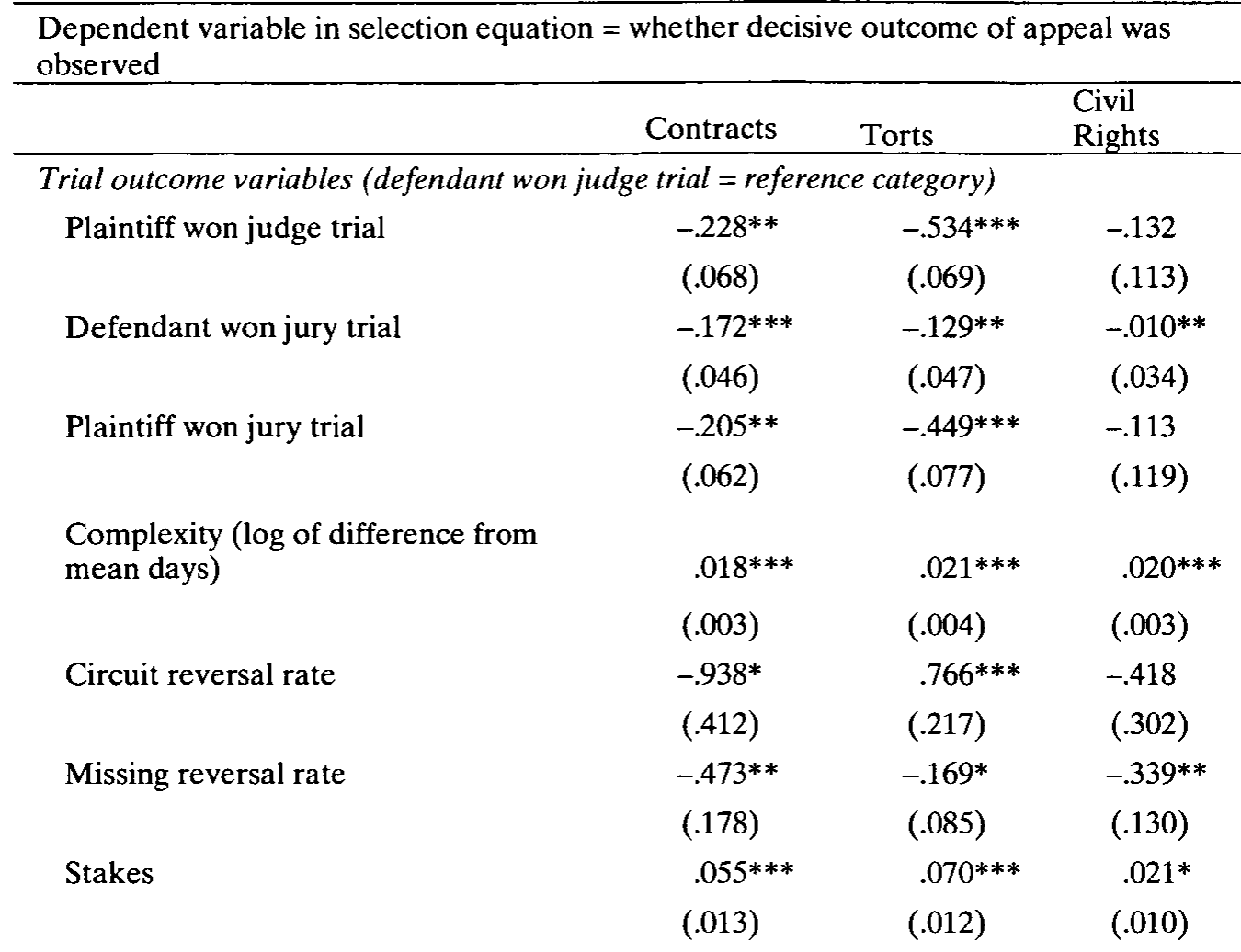

Other variables, and the Outcome Equation, are reported in Table 3 and the Appendix (panel A)

$\begin{array}{llll}\text { Number of judgment observations } & 9,932 & 15,848 & 22,315\end{array}$

Robust standard errors are in parentheses; ${ }^{*}$ represents $\mathrm{p}<.05,{ }^{* *} \mathrm{p}<.005,{ }^{* * *} \mathrm{p}<.0005$

Source: Administrative Office data.

Table 4 reports selected results of the model of the decision to appeal to a decisive outcome. This part of the bivariate probit analysis reveals the influences on this decision to appeal, rather than the outcome of the appeal. The universe of cases includes all trials with a definitive judgment for plaintiff or defendant.

Table 4 suggests that some factors affecting the decision to appeal are common to all groups of cases, while some factors differ. In all three major groups of cases, the stakes coefficient is positive and statistically significant. In keeping with basic economic theory, parties are more likely to appeal cases with higher stakes, regardless of subject area.

Another common factor is the consistently negative signs on the coefficients for three variables: "Plaintiff won judge trial," "Defendant won jury trial," and "Plaintiff won jury trial." The negative signs indicate that the reference category, "Defendant won judge trial," is the mode of trial and outcome of trial most likely to be appealed to a decisive outcome, regardless of subject area. This conclusion is tempered by the absence of a 
true choice between judge and jury trial in several classes of cases. For example, until the Civil Rights Act of 1991, plaintiffs in Title VII job discrimination cases had no right to a jury trial. ${ }^{40}$ But this same pattern with respect to defendant wins at judge trial emerged in our earlier work, which limited the sample to categories of cases with a true choice between judge and jury trial. $^{41}$

A third common factor is our proxy for complexity. The longer a case took to resolve compared to similar cases in its circuit, the more likely an appeal was. This effect exists at similar magnitude and significance for all three groups. We interpret this as evidence to mean that the more complex cases offer a greater possibility of reversible error and more room for disagreement about the trial court's rulings.

Unlike stakes, mode of trial, and complexity, the circuit's rate of reversal for a class of cases has dramatically different characteristics across the three groups ${ }^{42}$ In Torts cases, the positive, highly significant coefficient for "Circuit reversal rate" suggests, as we hypothesized, that the greater the rate of observed reversals, the greater the likelihood of appeal. In Contracts cases, in contrast, the effect is significant in the opposite direction: the greater the likelihood of reversal, the less likely an appeal. Perhaps the post-trial bargaining and settlement process differs across Contracts and Torts cases. In Civil Rights cases, the observed reversal rate is not significantly correlated with the decision to appeal. The differing influence of a circuit's reversal rates suggests an interesting area for further research about the decision to appeal.

Our present effort, however, focuses on appellate outcome. The models show that the anti-plaintiff effect on reversal rates survives strongly even while accounting for the decision to appeal.

\section{Empirical Results for Nontried Cases}

Our story, especially in Torts and Civil Rights cases, is one of appellate judges' disagreement with trial judges as well as with trial juries. If appellate and trial judges view litigants differently, that difference ought to emerge not only in tried cases, but also in cases resolved by district courts before trial. Trial judges may enter judgment for either party based on pretrial motions and documentary evidence. Then appellate judges may review those judgments.

Table 5, through two panels, explores appeal rates and reversal rates in cases resolved before trial. Panel A reports plaintiffs' and defendants' appeal and reversal rates across all case categories at all stages of trial court

40. See TheOdore Eisenberg, Civil RightS LEgislation 9 (4th ed. 1996).

41. See Clermont \& Eisenberg, Appeal, supra note 4, at 158 tbl.A1.

42. In our earlier division of cases into personal injury and nonpersonal injury classes, models also "[showed] stakes to correlate positively and significantly with the decision to appeal," and the effect of circuit reversal rate differed between the two large classes. Id. at $153 \mathrm{n} .58,158$. 
adjudication. The sample here includes not only tried cases, but also pretrial judgments. Then, for those pretrial judgments, Panel B reports appellate reversal rates for the six large groups of cases and for certain categories of cases of special interest.

Panel A shows that in all judgments, as presented in the first numerical column, the norm is that plaintiffs appeal much more, and obtain fewer reversals, than defendants. ${ }^{43}$ Plaintiffs appeal their numerous pretrial motion losses proportionately more than defendants appeal their losses. It seems likely that losing plaintiffs are not so apt to give up at this early stage, while victorious plaintiffs might have very strong cases decided on the merits or at least might now be willing to settle to avoid appeal. This relative frequency of plaintiffs' appeals leads to plaintiffs' getting fewer reversals. The pro-defendant tilt in the appellate court might also generate fewer reversals for plaintiff-appellants in nontried cases.

Thus, Panel A confirms a substantial defendant/plaintiff differential for all appeals, including those from pretrial judgments. The common element for all procedural stages is the defendants' relative success on appeal. An appellate court inclination in defendants' favor helps explain this observation.

In order to further study reversal rates for pretrial dispositions, Panel B takes Panel A's aggregated data and subdivides by case category. Reversal rates in nontried cases confirm the pattern in tried cases. Torts and Civil Rights plaintiffs do terribly on appeal compared to defendants. For the four Civil Rights categories, appellate reversal of plaintiffs' pretrial judgments either exceed $50 \%$ or are not statistically significantly different from $50 \%$. The poor appellate treatment of prisoners emerges most strongly in cases not tried, as both Habeas Corpus and Prisoner Civil Rights cases have plaintiffs' pretrial judgments reversed on appeal more than half the time. Appellate reversal of defendants' pretrial judgments is much rarer in the Civil Rights categories, producing extraordinarily high defendant/plaintiff differentials.

Tellingly, Panel B shows that the pattern of defendants' advantage transposes in the Negotiable Instruments category. Plaintiffs do better on appeal than defendants. Here, as discussed above, the perceived substantial plaintiff and the strong role of documentary evidence reduce appellate court fear of trial court pro-plaintiff bias.

43. Of course, judgments entered as a result of settlement are not likely to be appealed. So judg. ments entered as part of settlements make it difficult to make conclusions about rates of appeal. See id. at 154. 


\begin{tabular}{|c|c|c|c|c|c|c|c|}
\hline \multicolumn{8}{|c|}{$\begin{array}{c}\text { TABLE 5 } \\
\text { REVERSAL RATES IN FEDERAL CIVIL CASES RESOLVED BEFORE } \\
\text { TRIAL, FY 1988-1997 } \\
\text { Appeals from Judgments, Distinguished by Plaintiff or Defendant Win } \\
\text { Below }\end{array}$} \\
\hline \multicolumn{5}{|c|}{ All Judgments } & \multicolumn{3}{|c|}{ Tried Judgments } \\
\hline \multicolumn{3}{|c|}{ Overall number of judgments } & \multicolumn{2}{|c|}{621,917} & \multicolumn{3}{|c|}{60,605} \\
\hline \multicolumn{3}{|l|}{ Appeal rate (\%) } & \multicolumn{2}{|c|}{14.53} & \multicolumn{3}{|c|}{28.73} \\
\hline \multicolumn{3}{|c|}{ Affirmances and reversals } & \multicolumn{2}{|c|}{46,209} & \multicolumn{3}{|c|}{7,378} \\
\hline \multicolumn{3}{|l|}{ Reversal rate (\%) } & \multicolumn{2}{|c|}{14.44} & \multicolumn{3}{|c|}{18.37} \\
\hline \multicolumn{3}{|l|}{ Number of $P$ wins } & \multicolumn{2}{|c|}{282,665} & \multicolumn{3}{|c|}{26,037} \\
\hline \multicolumn{3}{|c|}{ Defendants' appeal rate (\%) } & \multicolumn{2}{|c|}{4.25} & \multicolumn{3}{|c|}{31.31} \\
\hline \multicolumn{3}{|c|}{ Affirmances and reversals } & \multicolumn{2}{|c|}{3,921} & \multicolumn{3}{|c|}{2,278} \\
\hline \multicolumn{3}{|c|}{ Defendants' reversal rate $(\%)$} & \multicolumn{2}{|c|}{29.05} & \multicolumn{3}{|c|}{32.53} \\
\hline \multicolumn{3}{|l|}{ Number of D wins } & \multicolumn{2}{|c|}{339,252} & \multicolumn{3}{|c|}{34,568} \\
\hline Plaintiffs' appeal & rate $(\%)$ & & 23. & .10 & & 26.78 & \\
\hline Affirmances and & reversals & & 42,2 & 288 & & 5,100 & \\
\hline Plaintiffs' reversa & l rate $(\%$ & & 13. & 09 & & 12.04 & \\
\hline Significance of $\mathrm{D} / \mathrm{I}$ & P differe & ntial & & 00 & & .000 & \\
\hline B. Appeals fro & $m$ Pretr & ial Judg & ments, $D$ & Distingui & shed by & Case C & egory \\
\hline & Overall & Defendant & s' Appeals & Plaintiffs' & Appeals & $\mathrm{D} / \mathrm{PD}$ & rential \\
\hline $\begin{array}{l}\text { Case-Category Num- } \\
\text { ber \& Name }\end{array}$ & $\begin{array}{c}\text { Reversal } \\
\text { Rate } \\
(\%) \\
\end{array}$ & $\begin{array}{c}\text { Affirm- } \\
\text { ances \& } \\
\text { Reversals }\end{array}$ & $\begin{array}{l}\text { Reversal } \\
\text { Rate (\%) }\end{array}$ & $\begin{array}{c}\text { Affirm- } \\
\text { ances \& } \\
\text { Reversals }\end{array}$ & $\begin{array}{l}\text { Reversal } \\
\text { Rate (\%) }\end{array}$ & $\begin{array}{l}\text { Size } \\
(\%)\end{array}$ & $\begin{array}{l}\text { Signif- } \\
\text { icance }\end{array}$ \\
\hline CONTRACTS & 18.98 & 1,284 & 20.64 & 3,105 & 18.29 & 2.35 & .076 \\
\hline $\begin{array}{l}140 \text { Negotiable In- } \\
\text { struments }\end{array}$ & 18.99 & 107 & 13.08 & 72 & 27.78 & -14.70 & .019 \\
\hline TORTS & 17.70 & 164 & 29.88 & 3,090 & 17.06 & 12.82 & .000 \\
\hline 365 Product Liability* & 17.19 & 44 & 34.09 & 759 & 16.21 & 17.88 & .006 \\
\hline Civil Rights & 10.56 & 443 & 51.92 & 24,595 & 9.81 & 42.11 & .000 \\
\hline 440 Other Civil Rights & 13.52 & 157 & 46.50 & 5,279 & 12.54 & 33.96 & .000 \\
\hline 442 Jobs & 11.66 & 76 & 44.74 & 4,025 & 11.03 & 33.71 & .000 \\
\hline 530 Habeas Corpus & 10.80 & 170 & 58.82 & 5,236 & 9.24 & 49.58 & .000 \\
\hline $\begin{array}{l}550 \text { Prisoner Civil } \\
\text { Rights }\end{array}$ & 8.38 & 40 & $\mathbf{5 7 . 5 0}$ & 10,055 & 8.18 & 49.32 & .000 \\
\hline LABOR LAWS & 23.00 & 370 & 37.84 & 1,904 & 20.12 & 17.72 & .000 \\
\hline $\begin{array}{l}\text { MISCELLANEOUS } \\
\text { STATUTORY ACTIONS }\end{array}$ & 22.64 & 632 & 32.12 & 2,181 & 19.90 & 12.22 & .000 \\
\hline OTHERS & 17.32 & 1,028 & 24.51 & 7,413 & 16.32 & 8.19 & .000 \\
\hline
\end{tabular}

*We combine the Administrative Office's seven other product liability categories (\#\# 195, 245, 315, $345,355,368 \& 385)$ into this one main category.

Source: Administrative Office data.

\section{Another Database}

A study of federal appeals over a much longer period of time is possible using the Appeals Court Data Base, funded by the National Science Foundation and compiled by Donald Songer. The database 
contains coded renditions of 18,195 randomly selected published opinions by the federal courts of appeals from calendar year 1925 through $1996 .^{44}$ We used that data to confirm our results. We began by narrowing the database to district court civil cases, and then looked at appeals by plaintiffs and defendants. This left a sample of 9,998 published opinions. Using logistic regression analysis, we studied reversal by controlling for defendant appeal, type of appellant and respondent, type of case, year, and circuit. ${ }^{45}$

The results for all tried and nontried judgments appear in Table 6. The significant, positive .172 coefficient for the variable "Defendant appeal" shows that the defendant/plaintiff differential has been present throughout the period, which mainly preceded the years covered in our own database. In results not reported in Table 6 , the highly significant effect grows in size during recent years, with the coefficient being .369 in the post-1980 period and being .501 in the post-1987 period. The results for only the tried judgments show a similar defendant/plaintiff differential over the period, but it loses significance in the smaller recent samples of increasingly filtered published opinions. ${ }^{46}$

This filtering brings up a limitation of this new database, namely, its reliance on published opinions. The rate of publishing federal courts of appeals' opinions has dropped substantially over the years. ${ }^{47}$ The Administrative Office's data for all appeals reveal a drop in the publication rate from almost $50 \%$ in 1976 to just over $20 \%$ in $2000 .{ }^{48}$ Moreover, publication skews seriously toward publishing reversals rather than affirmances. ${ }^{49}$ While our database built on the Administrative Office's data shows in Table I an affirmance rate for appeals from tried judgments of

44. For a description and the initial utilization of this database, see DONALD R. SONGER, ET AL., CONTINUITY AND CHANGE ON THE UNITED STATES COURTS OF APPEALS 145-52 (2000). A brief description appears in ASHLYN K. KUERSTEN \& DONALD R. SONGER, DECISIONS ON THE U.S. COURTS OF APPEALS 241-64 (2001). The actual database and its codebook is available at http://www.ssc.msu.edu/ $\sim$ pls/pljp/ctadata.html.

45. The Songer database's sampling structure changed over time, but our statistical models account for these different sampling techniques. We also account for the fact that the sample was stratified by year and that observations in the same circuit may not be independent. See, e.g., C.J. Skinner, Introduction to Part A, in ANALYSIS OF COMPLEX SURVEYS 23-58 (C.J. Skinner et al. eds., 1989).

46. In particular, the Songer database seems unreliable with respect to trials. For some reason, this database's sample skews dramatically toward reversal for tried cases, and especially for recent trials. It shows a shockingly low $44 \%$ affirmance rate for trials over the post- 1987 period. The drop is so dramatic that the $95 \%$ confidence interval does not come close to overlapping the $95 \%$ confidence interval for the comparable affirmance rate from our database. See Catherine Albiston, The Rule of Law and the Litigation Process: The Paradox of Losing by Winning, 33 LAW \& SOC'Y REV. 869, 883-85 (1999) (suggesting publication rate varies with procedural vehicle for decision).

47. See Deborah Jones Merritt \& James J. Brudney, Stalking Secret Law: What Predicts Publication in the United States Courts of Appeals, 54 VAND. L. REV. 71, 72, 75-76 (2001).

48. The database includes appropriate variables that allow us to make this calculation.

49. See KUERSTEN \& SONGER, supra note 44 , at $40-41$ (observing a $62 \%$ affirmance rate in their sample of federal appellate published opinions, but warning: "It is reasonable to expect, although there is not much empirical research on the subject, that cases with appeals that ... are decided with unpublished dispositions contain a much higher rate of loss for the appellants than those decisions that were announced with a published opinion."); Clermont \& Eisenberg, Appeal, supra note 4, at 130 n.10. 
$82 \%$, its comparable affirmance rate only for published appellate opinions drops to $63 \%$. The decreasing publication rate leads to a decreasing affirmance rate over recent time in the Songer database. More generally, when attempting to study the mass of cases, there is a danger, which increases with recent years, of limiting legal research to published opinions. $^{50}$

TABLE 6

LOGISTIC REgRESSION RESUlTS FOR FEDERAL CIVIL CASES, 1925-1996

\begin{tabular}{lcc}
\hline \multicolumn{2}{c}{ dependent variable = reversal; number of observations $=9,998$} \\
\hline Independent Variable & Coefficient & Significance \\
Defendant appeal & .172 & .003 \\
Appellant type (individual = reference) & & \\
$\quad$ business & .219 & .000 \\
$\quad$ nonprofit organization & .341 & .011 \\
$\quad$ federal government & .967 & .000 \\
local government & .438 & .006 \\
$\quad$ state government & .534 & .000 \\
other & .103 & .367 \\
$\quad$ unknown & .267 & .458 \\
Respondent type (individual = reference) & & \\
business & -.160 & .032 \\
nonprofit organization & -.176 & .278 \\
$\quad$ federal government & -.423 & .000 \\
local government & -.095 & .455 \\
$\quad$ state government & -.708 & .000 \\
other & -.207 & .101 \\
$\quad$ unknown & -.321 & .318 \\
Case group (contracts = reference) & & \\
$\quad$ torts & -.149 & .102 \\
civil rights & .216 & .009 \\
labor laws & -.026 & .835 \\
miscellaneous statutory actions & -.055 & .556 \\
others & -.041 & .602 \\
Year & .010 & .000 \\
Constant & -20.01 & .000 \\
\hline
\end{tabular}

Source: Donald Songer's published-opinion database.

50. See Merritt \& Brudney, supra note 47 , at 75 . Indeed, a large sample of published opinions in three circuits from 1980 to 1985 revealed a defendant/plaintiff differential that was largely limited to civil rights cases. See Theodore Eisenberg \& Stewart J. Schwab, What Shapes Perceptions of the Federal Court System?, 56 U. CHI. L. REV. 501, 517-18 (1989); cf. infra text accompanying notes 56-57 (discussing studies of affirmance effect). The result in a recent study by Paul W. Mollica, Employment Discrimination Cases in the Seventh Circuit, 1 EMPLOYEE RTS. \& EMP. POL'Y J. 63, 70-71 (1997), which showed a relatively strong plaintiffs' reversal rate on appeals of pretrial motions in a limited sample of employment discrimination cases, seems attributable to its reliance on published opinions. 


\section{5. "Haves vs. Have Nots" or "Defendants vs. Plaintiffs"?}

Songer's team argued that the winners in the federal courts of appeals tend to be "repeat-player haves." ${ }^{11}$ Looking at reversal-rate differentials, they observed that success visits the federal government, state governments, local governments, nonprofit organizations, businesses, and individuals in descending order. ${ }^{52}$ But they did not look for the defendant/plaintiff differential, and they did not use regression analysis to simultaneously control for factors such as plaintiff or defendant status, appellant or appellee status, case category, and time.

Our analysis, after applying the additional controls, confirms the "repeat-player haves" effect in the Songer database, as shown in Table 6. For example, businesses fare better than individuals both as appellants and as appellees. But the persisting significance of who appeals, represented by the "Defendant appeal" variable, suggests that the "haves vs. have nots" class of explanations is incomplete. There is also "a separate defendants' advantage worthy of study." 53

The earlier analysis of our database, after controlling for case selection, found little evidence to support the traditional "haves vs. have nots" class of explanations. Neither government litigants nor corporate litigants fared significantly differently from nongovernmental, noncorporate litigants in reversal rates in our comprehensive study of diversity cases. ${ }^{54}$ In the present study, the magnitudes of the defendant/plaintiff differentials in the large, important case categories of torts and civil rights exceed the "haves vs. have nots" differentials reported by Songer. Special appellate court suspicion of trial court activity in these cases seems to be at work. When the "have nots" are the trial court plaintiffs, the have-not explanations conjoin with the usual defendants' advantage. The result is a defendant/plaintiff differential of extraordinary magnitude.

\section{CONCLUSION}

Our new database, which matches federal trial court and appellate court cases, yields new insights into the appellate process. Prior work with

51. See SONGER ET AL., supra note 44, at 89-99; Donald R. Songer \& Reginald S. Sheehan, Who Wins on Appeal? Upperdogs and Underdogs in the United States Courts of Appeals, 36 AM. J. POL. SCI. 235, 253-55 (1992) (using a different database that included unpublished decisions, and performing logistic regressions); see also Terence Dunworth \& Joel Rogers, Corporations in Court: Big Business Litigation in U.S. Federal Courts, 1971-1991, 21 LAw \& SOC. INQUIRY 497, 502 (1996) ("Big business wins overwhelmingly, as plaintiff and defendant, in cases that involve it."); cf. Donald J. Farole, Jr., Reexamining Litigant Success in State Supreme Courts, 33 LAW \& SOC'Y REV. 1043 (1999) (studying state supreme court decisions); Wheeler et al., supra note 14, at 438-39, 442-44 (same).

52. SONGER ET AL., supra note 44 , at 98-99 tbl.4.8.

53. Clermont \& Eisenberg, Appeal, supra note 4, at 138.

54. See id. at 157 tbl.A1. Yet the Administrative Office's trial level data yield significant evidence of government strength as a litigant at the trial level. See THEODORE EISENBERG \& HENRY S. FARBER, The Government as Litigant: Further Tests of the CaSE SElEction Model (Nat'l Bureau of Econ. Research, Working Paper No. 7296, 1999). 
the database debunked the belief that jury trial verdicts are unusually resistant to appellate reversal. ${ }^{55}$

Further study of the database confirms prior findings of an "affirmance effect"- that is, appellate courts tend to affirm trial courts-but shows the effect to be substantially stronger than studies of published opinions reveal. Wheeler et al. concluded about fifteen years ago that "the greatest advantage among state supreme court litigants went to those who won in the lower courts... [appellees] enjoyed a roughly $20 \%$ advantage ... over appellants." ${ }^{.56}$ Eisenberg and Schwab found about a 33\% appellee advantage in a large study of federal appellate published opinions. ${ }^{57}$ The methodology used in both studies, focusing only on published opinions, understates the appellate success of those who won in the lower courts. Our new database suggests an affirmance rate of about $80 \%$, or a $60 \%$ appellee advantage.

Prior researchers have not systematically explored whether there is an advantage on appeal based on defendant or plaintiff status. We show that a defendants' advantage exists, accompanying the general tendency of appellate courts to affirm. Overall, Table 1 shows about a $21 \%$ defendants' advantage, after accounting for who won in the lower courts. Table 2 shows that this advantage often exceeds $21 \%$ in tort cases and always exceeds that percentage in civil rights cases. For Torts and Civil Rights cases, the magnitude of the defendants' advantage is at least that of the old view of the advantage of being the appellee rather than the appellant. The defendants' advantage in these cases reaches socially important levels. For other groups of cases, the defendants' advantage is smaller but significant or near significant.

We cannot prove directly that the defendants' advantage stems in substantial part from appellate court attitudes. To the extent our models reasonably account for the decision to appeal, the defendants' advantage does not stem exclusively from shrewd decision making by repeat players about which cases to appeal. Various observations-including the negation of the defendants' advantage in Negotiable Instruments cases, contrasted with its strength in Torts and Civil Rights cases-suggest that perceptions about classes of litigants do indeed drive the reversal rates.

Therefore, a likely major source of the defendants' advantage is judicial attitude. Differences in attitudes toward different classes of litigants must exist between appellate courts and trial courts. Probably, the operative difference is the appellate judges' misperceptions about the trial level treatment of plaintiffs. The appellate court, consequently, is more favorably disposed to the defendant than are the trial judge and the jury.

55. See Clermont \& Eisenberg, Appeal, supra note 4, at 130.

56. Wheeler et al., supra note 14 , at 437 .

57. See Eisenberg \& Schwab, supra note 50, at 517-18. 


\section{APPENDIX}

\section{Bivariate Probit Models of APPELlate OUTCOME AND THE}

\section{DECISION TO APPEAL}

A. Contracts, Torts, and Civil Rights

dependent variable in outcome equation $=$ reversal of trial result

dependent variable in selection equation $=$ whether decisive outcome of appeal was observed

\begin{tabular}{lccc}
\hline OUTCOME EQUATION & Contracts & Torts & $\begin{array}{c}\text { Civil } \\
\text { Rights }\end{array}$ \\
Trial outcome variables; Defendant & won judge trial & reference category \\
Plaintiff won judge trial & -.053 & $.942^{* * *}$ & $.824^{* *}$ \\
& $(.123)$ & $(.131)$ & $(.293)$ \\
Defendant won jury trial & -.102 & .120 & .051 \\
& $(.100)$ & $(.082)$ & $(.052)$ \\
Plaintiff won jury trial & .136 & $.723^{* * *}$ & $.701^{* *}$ \\
& $(.147)$ & $(.119)$ & $(.256)$ \\
Complexity (log of difference & $.021^{* *}$ & .007 & $.015^{* * *}$ \\
from mean days) & $(.007)$ & $(.010)$ & $(.004)$
\end{tabular}

Circuit dummy variables; D.C. Circuit $=$ reference category

$1^{\text {st }}$ Circuit

$2^{\text {nd }}$ Circuit

$3^{\text {rd }}$ Circuit

$4^{\text {th }}$ Circuit

$5^{\text {th }}$ Circuit

$6^{\text {th }}$ Circuit

$7^{\text {th }}$ Circuit

$8^{\text {th }}$ Circuit

$9^{\text {th }}$ Circuit

$10^{\text {th }}$ Circuit

$11^{\text {th }}$ Circuit

Case category dummy variables

$-.261$

(.180)

$-.420^{*}$

(.195)

$-.665^{*}$

(.286)

$-.536^{*}$

(.243)

$-.389 \dagger$

(.228)

$-.452 \dagger$

(.255)

$-.411^{*}$

(.192)

$-.452^{*}$

(.222)

$-.332 \dagger$

(.197)

$-.494 *$

(.241)

$-.337 \dagger$

(.197)
$-.191 * *$

(.057)

$-.077$

(.125)

$-.282$

(.179)

$-.347^{* * *}$

(.084)

$-.429 * * *$

(.088)

$-.378^{* *}$

(.121)

$-.201$

(.153)

$-.296^{*}$

(.124)

$-.242 *$

(.108)

$-.389 * *$

(.113)

$-.388^{* * *}$

(.087)
$-.043$

(.104)

.020

(.108)

$-.106$

(.069)

$-.194 \dagger$

$.200 \dagger$

(.119)

.007

(.071)

$-.001$

(.087)

General contract $=$ reference category

Insurance

$-.032$

$(.077)$ 
Marine contracts $\quad-.165$

Negotiable instruments

Other personal injury = reference category

Federal Employers' Liability

Marine torts

Motor vehicle

Medical malpractice

Product liability

Fraud

Other civil rights $=$ reference category

Jobs $-.186$ $(.083)^{*}$

Habeas corpus $-.188 \dagger$

Prisoner civil rights

Prisoner civil rights $-.333 * * *$ (.064)

Year of termination $-.002$ $.036^{* *}$ $-.010$

\begin{tabular}{cccc} 
& $(.012)$ & $(.012)$ & $(.009)$ \\
Constant & -1.183 & $-2.801^{* *}$ & -1.210 \\
& $(1.203)$ & $(1.070)$ & $(.836)$ \\
\hline
\end{tabular}

SELECTION EQUATION

Trial outcome variables; Defendant won judge trial = reference category

Plaintiff won judge trial

Defendant won jury trial

Plaintiff won jury trial

Complexity (log of difference from mean days)

Circuit reversal rate
$-.228 * *$

(.068)

$-.172 * * *$

(.046)

$-.205 * *$

(.062)

$.018 * * *$

(.003)

$-.938^{*}$

(.412)

$$
\begin{aligned}
& -.534 * * * \\
& (.069) \\
& -.129 * * \\
& (.047) \\
& -.449 * * * \\
& (.077) \\
& .021 * * * \\
& (.004) \\
& .766 * * * \\
& (.217)
\end{aligned}
$$
$-.010^{* *}$ (.034) $.020 * * *$ (.003) $-.418$ (.302) 


$\begin{array}{llll}\text { Missing reversal rate } & -.473^{* *} & -.169^{*} & -.339 * * \\ \text { Stakes } & (.178) & (.085) & (.130) \\ & .055^{* * *} & .070^{* * *} & .021^{*} \\ & (.013) & (.012) & (.010)\end{array}$

Case category dummy variables

General contract $=$ reference category

Insurance

.026

Marine contracts

Negotiable instruments

Other personal injury = reference category

Federal Employers' Liability

Marine torts

Motor vehicle

Medical malpractice

Product liability

Fraud

Other civil rights $=$ reference category

Jobs

Habeas corpus

Prisoner civil rights

Year of termination

Constant 


\begin{tabular}{lccc} 
Number of observations & 9,932 & 15,848 & 22,315 \\
Log likelihood & $-4,294.542$ & $-5,172.427$ & $-10,235.74$ \\
\hline
\end{tabular}

Robust standard errors are in parentheses; $\dagger \mathrm{p}<.1,{ }^{*} \mathrm{p}<.05,{ }^{* *} \mathrm{p}<.01,{ }^{* * *} \mathrm{p}<.001$

\section{B. Labor Laws, Miscellaneous Statutory Actions, and Others}

dependent variable in outcome equation $=$ reversal of trial result dependent variable in selection equation $=$ whether decisive outcome of appeal was observed

\begin{tabular}{|c|c|c|c|}
\hline OUTCOME EQUATION & Labor Laws & $\begin{array}{c}\text { Misc. } \\
\text { Statutory } \\
\text { Actions }\end{array}$ & Others \\
\hline \multicolumn{4}{|c|}{ Trial outcome variables; Defendant won judge trial $=$ reference category } \\
\hline Plaintiff won judge trial & $\begin{array}{l}.064 \\
(.357)\end{array}$ & $\begin{array}{l}.590^{* * *} \\
(.145)\end{array}$ & $\begin{array}{l}-.046 \\
(.270)\end{array}$ \\
\hline Defendant won jury trial & $\begin{array}{l}-.146 \\
(.215)\end{array}$ & $\begin{array}{l}.140 \\
(.118)\end{array}$ & $\begin{array}{l}.127 \\
(.143)\end{array}$ \\
\hline Plaintiff won jury trial & $\begin{array}{l}.442 \\
(.297)\end{array}$ & $\begin{array}{l}.418^{* *} \\
(.144)\end{array}$ & $\begin{array}{l}.592^{* * *} \\
(.148)\end{array}$ \\
\hline $\begin{array}{l}\text { Complexity (log of difference from } \\
\text { mean days) }\end{array}$ & $\begin{array}{l}.000 \\
(.015)\end{array}$ & $\begin{array}{l}-.003 \\
(.010)\end{array}$ & $\begin{array}{l}.013 \\
(.019)\end{array}$ \\
\hline \multicolumn{4}{|c|}{ Circuit dummy variables; D.C. Circuit $=$ reference category } \\
\hline $1^{\text {st }}$ Circuit & $\begin{array}{r}-1.378^{*} \\
(.663)\end{array}$ & $\begin{array}{l}-.553 \\
(.349)\end{array}$ & $\begin{array}{l}-7.426^{* * *} \\
(1.758)\end{array}$ \\
\hline $2^{\text {nd }}$ Circuit & $\begin{array}{r}-1.273 \\
(.783)\end{array}$ & $\begin{array}{l}-.140 \\
(.208)\end{array}$ & $\begin{array}{l}-6.641 * * * \\
(1.684)\end{array}$ \\
\hline $3^{\text {rd }}$ Circuit & $\begin{array}{r}-1.410 \dagger \\
(.780)\end{array}$ & $\begin{array}{l}-.344 \dagger \\
(.197)\end{array}$ & $\begin{array}{l}-6.667^{* * *} \\
(1.718)\end{array}$ \\
\hline $4^{\text {th }}$ Circuit & $\begin{array}{r}-1.027 \\
(.633)\end{array}$ & $\begin{array}{c}-.258 \dagger \\
(.146)\end{array}$ & $\begin{array}{l}-6.792^{* * *} \\
(1.698)\end{array}$ \\
\hline $5^{\text {th }}$ Circuit & $\begin{array}{r}-1.137 \dagger \\
(.650)\end{array}$ & $\begin{array}{l}-.463 \dagger \\
(.237)\end{array}$ & $\begin{array}{l}-6.892 * * * \\
(1.727)\end{array}$ \\
\hline $6^{\text {th }}$ Circuit & $\begin{array}{r}-1.473^{*} \\
(.724)\end{array}$ & $\begin{array}{l}-.213 \\
(.162)\end{array}$ & $\begin{array}{l}-6.793^{* * *} \\
(1.729)\end{array}$ \\
\hline $7^{\text {th }}$ Circuit & $\begin{array}{r}-1.024 \\
(.694)\end{array}$ & $\begin{array}{l}-.489 * \\
(.218)\end{array}$ & $\begin{array}{l}-6.594 * * * \\
(1.706)\end{array}$ \\
\hline $8^{\text {th }}$ Circuit & $\begin{array}{r}-1.389 \dagger \\
(.743)\end{array}$ & $\begin{array}{c}.006 \\
(.115)\end{array}$ & $\begin{array}{l}-6.814^{* * *} \\
(1.671)\end{array}$ \\
\hline $9^{\text {th }}$ Circuit & $\begin{array}{l}-.861 \\
(.652)\end{array}$ & $\begin{array}{l}-.510^{*} \\
(.197)\end{array}$ & $\begin{array}{l}-6.828^{* * *} \\
(1.688)\end{array}$ \\
\hline
\end{tabular}


$10^{\text {th }}$ Circuit

$$
-1.222^{*}
$$$$
-.702 \dagger
$$$$
-6.860 * * *
$$

$11^{\text {th }}$ Circuit

Case category dummy variables

Other labor litigation = reference category

Fair Labor Standards Act

Labor/Management Relations Act

ERISA

Other statutory actions $=$ reference category

Trademark

Securities, commodities, exchange

Tax suits

Year of termination

$-.039$

.022

$-.022$

(.026)

(.017)

Constant

N/A

\section{SELECTION EQUATION}

Trial outcome variables; Defendant won judge trial $=$ reference category

Plaintiff won judge trial

Defendant won jury trial

Plaintiff won jury trial

Complexity (log of difference from mean days)

Circuit reversal rate

Missing reversal rate

Stakes

$$
-.125
$$

.060

(.119)

.042

(.096)

.004

(.007)

.113

(.949)

$-.411^{*}$

$(.185)$

$.054^{*}$

(.022)

$\begin{array}{ll}-.302 * * * & -.345 * * * \\ (.072) & (.070) \\ -.064 & -.043 \\ (.084) & (.069) \\ -.435 * * * & -.310 * * * \\ (.086) & (.079)\end{array}$

$.012 \dagger$

(.006)

.727

(.621)

$-.112$

(.153)

$.031^{*}$

(.013)
$.017^{* * *}$

(.004)

N/A

$-.461 * *$

$.050 * * *$

(.012) 
Case category dummy variables

Other labor litigation = reference category

Fair Labor Standards Act .003

(.123)

Labor/Management Relations Act

ERISA

Other statutory actions $=$ reference category

Trademark

Securities, commodities, exchange

Tax suits

Year of termination

$-.024 *$

Constant

(.010)

$-.032 * *$

$-.010$

Constant

1.165

(.011)

(.009)

$P$

$1.805 \dagger$

$-.021$

.500

Number of outcome observations

(.872)

$-.875 \dagger$

$-.245$

Number of outcome observations

337

(.174)

(.713)

Number of observations

2,446

430

659

Log likelihood

$-1,121.042$

3,028

6,961

Robust standard errors are in parentheses; $\dagger \mathrm{p}<.1,{ }^{*} \mathrm{p}<.05,{ }^{* *} \mathrm{p}<.01,{ }^{* * *} \mathrm{p}<.001$ 